\title{
Transient reduction of human left ventricular mass in carnitine depletion induced by antibiotics containing pivalic acid
}

\author{
K Abrahamsson, M Mellander, B O Eriksson, E Holme, U Jodal, A Jönsson, S Lindstedt
}

\begin{abstract}
Objective-To study the effect of induced carnitine depletion on myocardial structure and function.

Subjects and Design-7 healthy adult volunteers given $1200 \mathrm{mg}$ pivmecillinam per day for 7-8 weeks were studied by echocardiography before and after 7-8 weeks of treatment and a 15 months follow up after the treatment period.

Setting-Teaching hospital.

Main outcome measures-Carnitine concentration in serum, urine, and muscle and echocardiographic measurements.

Results-After 7-8 weeks of treatment the median free serum carnitine concentration was reduced to $7 \%$ and the median total muscle carnitine concentration to $46 \%$ of the pretreatment levels. The median diastolic interventricular septum thickness decreased by $14 \%$ (mean $26 \%$, $P=0.028)$ and the median left ventricular mass by $10 \%$ (mean $20 \%, P=0.018$ ). Fifteen months later these dimensions had increased but not completely returned to pretreatment values.

Conclusions-Extended treatment with pivalic acid containing antibiotics causes carnitine depletion which may lead to changes in cardiac structure.
\end{abstract}

(Br Heart f 1995;74:656-659)

Keywords: carnitine depletion; left ventricular mass; antibiotics; pivalic acid

Carnitine is essential for fatty acid transport through the inner mitochondrial membrane and thus for energy production in skeletal and cardiac muscle, which are dependent on fatty acid oxidation. ${ }^{1}$ Most carnitine in the body is found in muscle $(92-97 \%){ }^{2}$ Strictly vegetarian adults have a total carnitine concentration in urine of about $25 \%$ of those on a mixed diet. $^{3}$ This indicates that the daily turnover represents both endogenous synthesis of carnitine and carnitine originating from meat in the diet. It is not known whether an increased demand for carnitine causes increased endogenous synthesis, but previous studies on the rate of replenishment indicate that there is no significant compensatory increase. ${ }^{4}$

Depletion of the body carnitine stores can be induced by treatment with pivalic acid containing drugs such as pivampicillin and pivmecillinam. ${ }^{4-6}$ Pivalic acid forms an ester with carnitine, pivaloylcarnitine, which is excreted in the urine. After one to two days of treatment with pivalic acid containing drugs the concentration of free serum carnitine in adults was reduced to about $50 \%$, and after 7 days to about $25 \%$ of the initial values. ${ }^{6}$ Depletion of the muscle carnitine stores takes considerably longer. ${ }^{2}$ With a body pool of 100 mmol in a $70 \mathrm{~kg}$ human adult ${ }^{7}$ it would take about 50 days to reduce the muscle carnitine concentration to $50 \%$ of the initial value. Long term treatment with low doses of drugs containing pivalic acid to prevent urinary tract infection in children resulted in severe depletion of the body carnitine stores, measured as a very low carnitine concentration in serum and skeletal muscle. ${ }^{4}$ Some of these children showed impaired ketone body production during fasting.

When given to rats, pivalic acid containing drugs caused reduction in the serum levels of carnitine.$^{89}$ Although this reduction was not as marked as in humans, a concomitant decrease of the carnitine concentration in the rat myocardium was observed. To study the effect of carnitine depletion on the human heart, we analysed the myocardial structure and function of healthy volunteers by echocardiography before and after administration of pivmecillinam.

\section{Methods}

SUBJECTS

Seven healthy volunteers, five women and two men, aged 17-54 years, were studied. To be accepted for the study, normal findings were required for medical history, physical examination, and electrocardiography. Normal values were found also for blood haemoglobin and sedimentation rate. No albuminuria, glycosuria, or haematuria was present.

No hypertensive subjects were included in the study. Subjects had a normal heart rate at rest which did not change during the study period.

Because of the season, after four weeks of the study period, subject No 7 travelled by bus instead of by bicycle to get to work $(10 \mathrm{~km}$ per day). None of the others changed their physical activity.

Subject No 6 was a 54 year old woman and the oldest of the volunteers. She travelled by bicycle to her work on five days a week throughout the study period ( $14 \mathrm{~km}$ per day). Otherwise she was not active in any sport.

The subjects were told to keep to a varied diet but to avoid meals very rich in fat or carbohydrates. All food and beverages were 
recorded for three days before the test procedures. No alcohol or physical exercise was allowed during $24 \mathrm{~h}$ before the procedures. Urine samples were frozen every other day to check compliance with taking the pivmecillinam. No other medication was permitted. The study was approved by the local ethics committee.

\section{INVESTIGATIVE PROCEDURE}

After $4 \mathrm{~h}$ of fasting, blood and muscle samples were obtained for analysis of carnitine. Electrocardiography and echocardiography were done. Thereafter, daily oral administration of $1200 \mathrm{mg}$ pivmecillinam $(2.7 \mathrm{mmol})$ was started and continued for 7-8 weeks (mean 54 days, range 49-56 days).

The test procedure was repeated at the end of the treatment period. Fifteen months after the treatment period, echocardiography was carried out again in five of the seven subjects (two subjects were then living abroad).

\section{METHODS}

The muscle biopsies were done with a concotome. A local anaesthetic, carbocain $1 \%$, was injected subcutaneously and down to the fascia but not into the muscle. Samples with a weight of $50-80 \mathrm{mg}$ were obtained from the lateral part of musculus vastus lateralis and immediately frozen in liquid nitrogen and stored at $-70^{\circ} \mathrm{C}$.

Carnitine in serum, urine, and muscle was determined by the method described by

Table 1 Carnitine levels before and after 7-8 weeks of treatment with pivmecillinam in seven subjects. Values are medians (range)

\begin{tabular}{|c|c|c|c|}
\hline & $\begin{array}{l}\text { Before } \\
\text { treatment }\end{array}$ & $\begin{array}{l}\text { After } \\
\text { treatment }\end{array}$ & $\begin{array}{l}\text { Difference } \\
\text { Pvalue }\end{array}$ \\
\hline $\begin{array}{l}\text { Serum total carnitine } \\
(\mu \mathrm{mol} / 1)\end{array}$ & $42 \cdot 0(24 \cdot 0-50 \cdot 0)$ & $12 \cdot 0(6 \cdot 3-17 \cdot 0)$ & 0.018 \\
\hline $\begin{array}{l}\text { Serum acyl carnitine } \\
(\mu \mathrm{mol} / \mathrm{l})\end{array}$ & $3.6(0.9-5.4)$ & $7 \cdot 8(4 \cdot 3-10 \cdot 0)$ & 0.018 \\
\hline $\begin{array}{l}\text { Serum free carnitine } \\
(\mu \mathrm{mol} / 1)\end{array}$ & $38 \cdot 4(22 \cdot 6-46 \cdot 6)$ & $2 \cdot 7(2 \cdot 0-7 \cdot 0)$ & 0.018 \\
\hline $\begin{array}{l}\text { Muscle total carnitine } \\
(\mu \mathrm{mol} / \mathrm{g} \text { protein })\end{array}$ & $17 \cdot 0(9 \cdot 8-19 \cdot 0)$ & $7 \cdot 8(6 \cdot 7-10 \cdot 0)$ & 0.028 \\
\hline $\begin{array}{l}\text { Muscle acyl carnitine } \\
\text { ( } \mu \text { mol/g protein })\end{array}$ & $6 \cdot 9(1 \cdot 2-9 \cdot 6)$ & $3 \cdot 9(3 \cdot 3-4 \cdot 9)$ & ns \\
\hline $\begin{array}{l}\text { Muscle free carnitine } \\
(\mu \mathrm{mol} / \mathrm{g} \text { protein })\end{array}$ & $10 \cdot 8(2 \cdot 9-13 \cdot 8)$ & $3 \cdot 9(2 \cdot 1-6 \cdot 5)$ & 0.042 \\
\hline $\begin{array}{l}\text { Urine total carnitine } \\
(\mathrm{mmol} / \mathrm{mol} \text { creatinine })\end{array}$ & $18 \cdot 0(11 \cdot 0-41 \cdot 0)$ & $91 \cdot 0(82 \cdot 0-114 \cdot 0)$ & 0.018 \\
\hline $\begin{array}{l}\text { Urine acyl carnitine } \\
\text { (mmol/mol creatinine) }\end{array}$ & $11 \cdot 0(9 \cdot 5-19 \cdot 0)$ & $91 \cdot 0(82 \cdot 0-114 \cdot 0)$ & 0.018 \\
\hline $\begin{array}{l}\text { Urine free carnitine } \\
\text { (mmol/mol creatinine) }\end{array}$ & $7 \cdot 0(1 \cdot 4-25 \cdot 0)$ & $0.0(0.0-1 \cdot 0)$ & 0.018 \\
\hline
\end{tabular}

*Wilcoxon non-parametric signed rank test for paired samples.

Table 2 Results of echocardiographic examination before and after 7-8 weeks treatment with pivmecillinam in seven subjects. Values are medians (range)

\begin{tabular}{|c|c|c|c|c|}
\hline & $\begin{array}{l}\text { Before } \\
\text { treatment }\end{array}$ & $\begin{array}{l}\text { After } \\
\text { treatment }\end{array}$ & $\begin{array}{l}\text { Difference } \\
P \text { value }\end{array}$ & $\begin{array}{l}\text { Confidence } \\
\text { interval }\end{array}$ \\
\hline $\begin{array}{l}\text { LA/Ao } \\
\text { LVIDd (mm) }\end{array}$ & $\begin{array}{c}1.22(0.96-1.47) \\
45.3(44.8-49.9)\end{array}$ & $\begin{array}{c}1.04(0.94-1.44) \\
48.3(42.1-51.9)\end{array}$ & ns & -1.15 to 3.55 \\
\hline LVSF (\%) & $33.0(29 \cdot 0-44 \cdot 0)$ & $37 \cdot 3(28 \cdot 3-47 \cdot 3)$ & $\begin{array}{l}\text { ns } \\
\text { ns }\end{array}$ & נ5. \\
\hline $\mathrm{EF}(\%)$ & $61 \cdot 7(55 \cdot 3-75 \cdot 0)$ & $67 \cdot 0(54 \cdot 0-78 \cdot 3)$ & ns & \\
\hline $\mathrm{SV}(\mathrm{ml} /$ stroke $)$ & $62.8(55.5-68.7)$ & $70 \cdot 2(45 \cdot 9-92 \cdot 8)$ & ns & \\
\hline LVO ( $1 / \mathrm{min})$ & $3.58(3.21-3.98)$ & $4 \cdot 20(2 \cdot 99-5 \cdot 48)$ & ns & \\
\hline LVPWd (mm) & $9 \cdot 8(6 \cdot 3-10 \cdot 9)$ & $7 \cdot 8(5 \cdot 5-11 \cdot 5)$ & & -0.30 to 2.0 \\
\hline IVSd (mm) & $8 \cdot 1(6 \cdot 1-15 \cdot 3)$ & $7 \cdot 0(6 \cdot 1-9 \cdot 1)$ & 0.028 & 0.35 to 5.10 \\
\hline LVM (g) & $135 \cdot 1(99 \cdot 0-297 \cdot 2)$ & $121.9(73.5-237.3)$ & 0.018 & $7 \cdot 95$ to $82 \cdot 1$ \\
\hline
\end{tabular}

$\mathrm{EF}$, ejection fraction (\%); IVSd, interventricular septal thickness in diastole; LA/Ao, left atrial/aortic root ratio; LVIDd, left ventricular internal dimension in diastole; LVM, left ventricular mass; LVO, left ventricular output; LVPWd, left ventricular posterior wall thickness in diastole; LVSF, left ventricular shortening fraction (\%); SV, stroke volume.

*Wilcoxon non-parametric signed rank test for paired samples.
Cederblad and Lindstedt, ${ }^{10}$ with modifications. ${ }^{6}$

$M$ mode echocardiographic measurements were obtained with an Acuson $128 \mathrm{XP} / 10 \mathrm{sec}-$ tor scanner using a 3.5 or $2.0 \mathrm{MHz}$ transducer. Left atrial (LA) and aortic (Ao) root diameters, as well as left ventricular internal dimension, left ventricular posterior wall thickness, and interventricular septal thickness in systole and diastole, were measured as recommended by the committee on $M$ mode standardisation of the American Society of Echocardiography. ${ }^{11}$ Thus the LA/Ao ratio was measured in a parasternal long axis section of the heart in systole. The aortic root diameter was measured from the leading edge of the anterior aortic wall echo to the leading edge of the posterior aortic wall echo. The left atrial diameter was measured from the leading edge of the posterior aortic wall echo to the leading edge of the posterior atrial wall echo. The left ventricular dimensions (LVIDd), as well as the interventricular septal and posterior wall diameters (IVSd and LVPWd), were also measured in a parasternal long axis section of the heart at the level of the tip of the mitral valve, using leading edge technology as described for LA/Ao ratio.

Each variable was taken as the mean of three consecutive measurements. The left atrial/aortic root ratio and the left ventricular shortening fraction were calculated from the $M$ mode measurements. In addition, the left ventricular ejection fraction, stroke volume and left ventricular output were calculated according to Teichholtz et al. ${ }^{12}$ The left ventricular mass (LVM) was calculated using the formula LVM $(\mathrm{g})=1.04[(\mathrm{LVIDd}+\mathrm{PWd}+$ IVSd $\left.)^{3}-(\text { LVIDd })^{3}\right]-13 \cdot 6 . .^{13}$

The coefficient of variation for repeated measurements of echocardiographic variables was determined in seven subjects with six measurements for each subject. The coefficient of variation was $12.5 \%$ for interventricular septal thickness in diastole (IVSd), 3.7\% for left ventricular inner diameter in diastole (LVIDd), and $10 \cdot 7 \%$ for left ventricular posterior wall thickness in diastole (LVPWd).

Statistical evaluation was performed using a non-parametric method, the Wilcoxon signed rank test for paired samples. Approximate 95\% confidence intervals based on HodgeLehmans estimate ${ }^{14}$ were calculated conservatively (exact $95.3 \%$ confidence intervals) for left ventricular mass and the three variables included in the formula given above.

\section{Results}

After treatment with pivmecillinam, the serum free carnitine concentration decreased from a median value of $38.4 \mu \mathrm{mol} / 1$ to $2.7 \mu \mathrm{mol} / 1$. The median concentration of total skeletal muscle carnitine decreased from $17.0 \mu \mathrm{mol} / \mathrm{g}$ protein before to $7.8 \mu \mathrm{mol} / \mathrm{g}$ protein after treatment (table 1).

The echocardiographic results are shown in table 2. All subjects showed a decrease in median left ventricular mass by $10 \%$ (mean $20 \%$ ) (figure). There was also a decrease in 

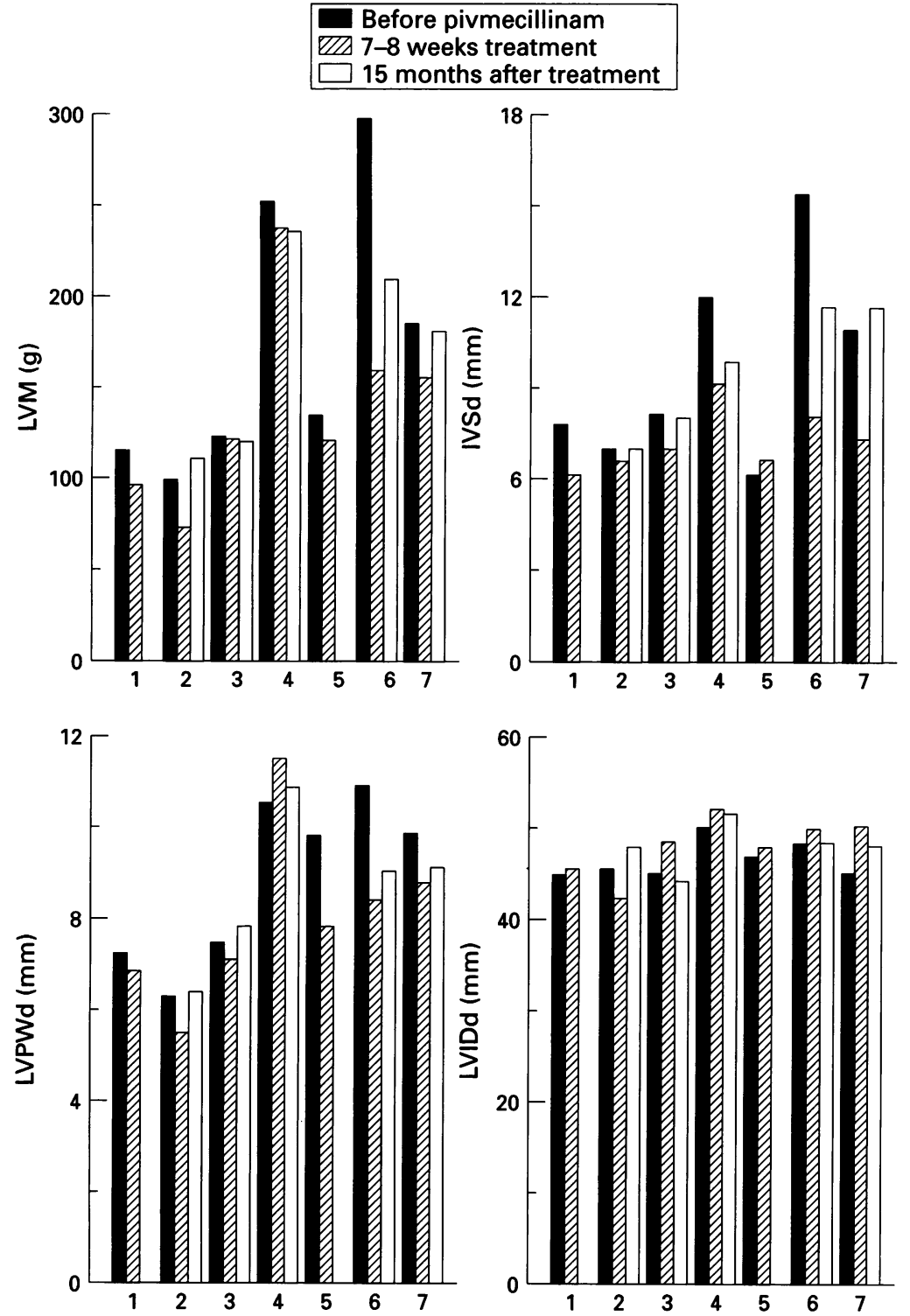

Left ventricular mass (LVM), interventricular septal thickness in diastole (IVSd), left ventricular posterior wall thickness in diastole (LVPWd) and left ventricular internal dimension in diastole (LVIDd) before pivmecillinam, after 7-8 weeks treatment with pirmecillinam, and 15 months later. echocardiographic findings had essentially returned to pretreatment values (figure). The median left ventricular mass had increased to $180.8 \mathrm{~g}$ and the median interventricular septal thickness in diastole to $9 \cdot 8 \mathrm{~mm}$ (table 3 ).

\section{Discussion}

In primary carnitine deficiency both hypertrophic and dilated cardiomyopathy occur. ${ }^{15-19}$ In several genetic disorders carnitine stores are depleted because of pathological accumulation of organic acids. ${ }^{20}$ However, little is known about cardiac involvement in these disorders, although cardiomegaly is a common feature, for example in children with long chain 3-hydroxyacyl-CoA dehydrogenase deficiency. ${ }^{21-24}$ In cases with fatty acid oxidation disorders it is not possible to decide whether the cardiomyopathy is caused by the primary fatty acid oxidation defect or, for example, by the secondary carnitine deficiency.

In our study, administration of a pivalic acid containing drug for seven to eight weeks caused a decrease of the median free serum carnitine concentration to $7 \%$ of the control levels and of median total muscle carnitine concentration to $46 \%$ of control levels. Therefore it is reasonable to suppose that there is also carnitine depletion in cardiac muscle tissue. Furthermore Diep et $a l^{25}$ recently showed that rats treated with pivampicillin orally had the highest pivaloylcarnitine concentration in brown adipose tissue as well as in cardiac muscle. The concentration of pivaloylcarnitine as a percentage of free carnitine was six times higher in cardiac muscle than in skeletal muscle. As carnitine deficiency has been reported to be associated with cardiac hypertrophy we were surprised to find a significantly decreased left ventricular myocardial mass in our carnitine deficient subjects. It is possible, however, that the initial response of the myocardium to carnitine deficiency may be different from what is observed at later stages of the disease, when the cardiomyopathic state is established. A decrease of the median left ventricular mass by $10 \%$ (mean 20\%) may seem small but its restoration after the end of the treatment period indicates that the phenomenon is related to the treatment.

Drugs containing pivalic acid are widely used against urinary tract infections. The manufacturers recommend a treatment period of 7-10 days. However, patients with complicated infections are sometimes treated for several weeks and those with recurrences may be given repeated courses, where the drug-free periods are too short to allow body carnitine stores to be restored. Our results suggest that such patients may be at risk of developing cardiac changes. Although the effect on the myocardial function was reversible over a period of about 15 months, a decrease of cardiac muscle mass may still be of significance to the patient, especially if myocardial function is already decreased secondary to other causes such as coronary insufficiency. 
This study was supported by the Swedish Medical Research Council (project No 9516, 585, 10823), the Gothenburg Medical Association, the Research Foundation of the Children's Hospital, the Free Masonry Orphanage Foundation, Idrottens Forskningsråd, the Swedish National Fssociation against Heart and Chest Diseases, and Leo Association against Heart and Chest Diseases, and Leo Desearch Foundation, Ballerup, Denmark. Many thanks to Dan Weinfeld, $M D$, for excell
tions of confidence intervals.

1 Bremer J. Carnitine-metabolism and functions. Physiol Rev 1983;63:1420-80.

2 Rebouche CJ, Engel AG. Kinetic compartmental analysis of carnitine metabolism in the human carnitine deficiency syndromes. 7 Clin Invest 1984;73:857-67.

3 Lombard KA, Olson AL, Nelson SE, Rebouche CJ Carnitine status of lactovegetarians and strict vegetarian adults and children. Am $₹$ Clin Nutr 1989;50: 301-6.

4 Holme E, Jodal U, Lindstedt S, Nordin I. Effects of pivalic acid-containing prodrugs on carnitine homeostasis and on response to fasting in children. Scand $\mathcal{f}$ Clin Lab Invest 1992;52:361-72.

5 Melegh B, Kerner J, Bieber LL. Pivampicillin-promoted excretion of pivaloylcarnitine in humans. Biochem Pharmacol 1987;36:3405-9.

6 Holme E, Greter J, Jacobson C-E, Lindstedt S, Nordin I Kristiansson $\mathrm{B}$, et al. Carnitine deficiency induced by pivampicillin and pivmecillinam therapy. Lancet 1989;ii: 469-73.

7 Engel AG, Rebouche CJ. Carnitine metabolism and inborn errors. $\mathcal{F}$ Inherit Metab Dis 1984;suppl 1:41-66.

8 Bianchi PB, Davis AT. Sodium pivalate treatment reduce tissue carnitines and enhances ketosis in rats. $\mathcal{f}$ Nutr 1991;121:2029-36.

9 Diep QN, Bøhmer T, Schjerven L. Reduced carnitine and ketogenesis in the pivampicillin treated rat. Biochem Pharmacol 1992;44:1226-8.

10 Cederblad G, Lindstedt S. A method for the determination of carnitine in the picomole range. Clin Chim Acta 1972, 37:235-43.

11 Sahn DJ, De Maria A, Kisslo J, Weyman A Recommendations regarding quantitation in M-mode echocardiography: results of a survey of echocar
graphic measurements. Circulation 1978;58:1072-83.

12 Teichholz LE, Kreulen T, Herman MV, Gorlin R Problems in echocardiographic volume determinations: echographic-angiographic correlations in the presence or absence of asynergy. Am f Cardiol 1976;37:7-11.

13 Devereux RB, Reichek N. Echocardiographic determination of left ventricular mass in man. Circulation 1977;55: 613-8.

14 Gardner MJ, Altman DG. In: Statistics with confidence. London: BMJ Publishing Group, 1989;76-8.

15 Eriksson BO, Lindstedt S, Nordin I. Hereditary defect in carnitine membrane transport is expressed in skin fibroblasts. Eur $\mathcal{f}$ Pediatr 1988;147:662-3.

16 Eriksson BO, Gustafson B, Lindstedt S, Nordin I. Transport of carnitine into cells in hereditary carnitine deficiency. $\mathcal{F}$ Inherit Metab Dis 1989;12:108-11.

17 Tein I, De Vivo DC, Bierman F, Pulver P, De Meirleir LJ, Cvitanovicsojat L, et al. Impaired skin fibroblast carnitine uptake in primary systemic carnitine deficiency manifested by childhood carnitine-responsive cardiomyopathy. Pediatr Res 1990;28:247-55.

18 Stanley CA, DeLeeuw S, Coates PM, Vianey-Liaud C, Divry P, Bonnefont JP, et al. Chronic cardiomyopathy and weakness or acute coma in children with a defect in carnitine uptake. Ann Neurol 1991;30:709-16.

19 Garavaglia B, Uziel G, Dworzak F, Carrara F, Didonato S. Primary carnitine deficiency: heterozygote and intrafaPrimary carnitine deficiency: heterozygote and intrafa-

20 DiDonato S, Garavaglia B, Rimoldi M, Carrara F. Clinical and biomedical phenotypes of carnitine deficiencies. In: Ferrari R, DiMauro S, Sherwood G, eds. L-carnitine and
its role in medicine: from function to therapy. New York: its role in medicine: from function

21 Hagenfeldt L, von Døbeln U, Holme E, Alm J, Brandberg $\mathrm{G}$, Enocksson $\mathrm{E}$, et al. 3-Hydroxydicarboxylic aciduria-a fatty acid oxidation defect with severe prognosis. $\mathcal{F}$ Pediatr 1990;116:387-92.

22 Venizelos N, Ijlst L, Wanders RJA, Hagenfeldt L. $\beta$ Oxidation enzymes in fibroblasts from patients with 3hydroxycarboxylic aciduria. Pediatr Res 1994;36:111-4.

23 Jackson S, Bartlett K, Land J, Moxon ER, Pollitt RJ, Leonard JV, et al. Long-chain 3-hydroxyacyl-CoA dehydrogenase deficiency. Pediatr Res 1991;29:406-11.

24 Wanders RJA, Ijlst L, Poggi F, Bonnefont JP, Munnich A, Brivet $M$, et al. Human trifunctional protein deficiency: a new disorder of mitochondrial fatty acid $\beta$-oxidation. Biochem Biophys Res Commun 1992;188:1139-45.

25 Diep QN, Bøhmer T, Skrede S. Formation of pivaloylcarnitine in heart and brown adipose tissue in the rat. Biochim Biophys Acta 1995;1243:65-70. 